\title{
Author`s Reply
}

To the Editor,

Many thanks to the authors for their important contribution for paper entitled "The effect of caffeic acid phenethyl ester on isoproterenol-induced myocardial injury in hypertensive rats".

In our study, although the caffeic acid phenethyl ester (CAPE) application route was not defined in the main text, it was specified in the abstract section. The CAPE solvent used in our study is similar to that used in our earlier study (1). In this study, CAPE (Sigma, >97\% pure) was dissolved in $95 \%$ ethanol (total $0.1 \mathrm{cc}$ volume) and it was then diluted 10 times with saline. Consequently, $10 \%$ ethanol at $0.1 \mathrm{cc} /$ day was administered to each rat. All groups received an equal volume of the ethanol/ saline vehicle solution (2).

Selçuk İlhan

Department of Pharmacology, Faculty of Medicine, Firat University; Elazı̆̆-Turkey

\section{References}

1. Oktar S, Aydın M, Yönden Z, Alçin E, İlhan S, Nacar A. Effects of caffeic acid phenethyl ester on isoproterenol-induced myocardial infarction in rats. Anatol J Cardiol 2010; 10: 298-302. [CrossRef]

2. Çağlı K, Bağcı C, Güleç M, Cengiz B, Akyol O, Sarı I, et al. In vivo effects of caffeic acid phenethyl ester on myocardial ischemia-reperfusion injury and apoptotic changes in rats. Ann Clin Lab Sci 2005; 35: 440-8.

Address for Correspondence: Dr. Selçuk IIlhan,

Fırat Üniversitesi Tıp Fakültesi,

Tıbbi Farmakoloji Anabilim Dalı, 23200, Elazığ-Türkiye

Phone: +90 42423700 00-4665

E-mail: selcukilhan52@gmail.com 